\title{
Manajemen Konflik dalam Pelaksanaan Program Gerakan Mamuju Mapaccing di Kabupaten Mamuju
}

\section{Conflict Management in the Implementation of the Mamuju Mapaccing Movement Program in Mamuju Regency}

\section{Inten Suweno ${ }^{1}, \mathrm{Alwi}^{2}$, Gita Susanti ${ }^{3}$}

1Departemen Administrasi Pembangunan, Universitas Hasanuddin, Indonesia. E-mail : inten.suweno95@yahoo.com 2Departemen Administrasi Pembangunan, Universitas Hasanuddin, Indonesia. E-mail : alwifisip@gmail.com ${ }^{3}$ Departemen Administrasi Pembangunan, Universitas Hasanuddin, Indonesia. E-mail : gitasusanti65@gmail.com

\section{ARTICLE INFO}

Keywords: Conflict, Conflict Management, Mamuju Mapaccing Movement Program.

Kata kunci: Konflik, Manajemen Konflik, Program Gerakan Mamuju Mapaccing.

\section{How to cite:}

Suweno, I., Alwi, Susanti, G. (2020). Manajemen Konflik Dalam Pelaksanaan Program Gerakan Mamuju Mapaccing di Kabupaten Mamuju. JAKPP (Jurnal Analisis Kebijakan dan Pelayanan Publik), 6(1), 35-48.

\section{ABSTRACT}

This study aims to examine the Conflict Management in the Implementation of the Mamuju Mapaccing Movement Program in Mamuju Regency using Conflict Theory put forward by Robbins (1998). This research is qualitative. Data collection is done through observation, interviews and literature. Data from observations and interviews are presented in the form of documentation of the object of research. Data from the results of the literature are presented in the form of quotations to obtain research findings. The data obtained are analyzed and processed using data analysis techniques that start from data reduction, data presentation, then start the conclusion / verification. The results showed that the source of conflict in the implementation of the Mamuju Mapaccing Movement program was the work of interdependence between the Department of Environment and Hygiene with the Kelurahan, representing one-way work, differentiated, related existence, and sources of information related to the source of danger. Therefore, the conflict resolution effort that must be carried out is also a replacement between the existing units between the Environment and Hygiene Office with the Kelurahan, a support system to ride the bandi, as well as efforts to increase resources in implementing the Mamuju Mapaccing Movement Program. Thus, the program will be implemented well and effectively. The results showed that the source of the conflict came from the interdependence of work between the Department of Environment and Hygiene with the Kelurahan, the dependence of one-way work, the high horizontal differentiation between Kelurahans, as well as differences in evaluation criteria and reward systems in implementing the Mamuju Mapaccing Movement Program.

\section{Abstrak}

Penelitian ini bertujuan untuk mengkaji tentang Manajemen Konflik Dalam Pelaksanaan Program Gerakan Mamuju Mapaccing di Kabupaten Mamuju dengan menggunakan Teori Konflik yang dikemukakan oleh Robbins (1998). 
Penelitian ini bersifat kualitatif. Pengumpulan data dilakukan melalui observasi, wawancara dan kepustakaan. Data dari hasil observasi dan wawancara disajikan dalam bentuk dokumentasi terhadap objek penelitian. Data dari hasil kepustakaan disajikan dalam bentuk kutipan-kutipan untuk memperkuat temuan penelitian. Data yang diperoleh dianalisis dan diolah dengan menggunakan teknik analisis data yang dimulai dari reduksi data, penyajian data, kemudian pengambilan kesimpulan/verifikasi.

Hasil penelitian menunjukkan bahwa sumber konflik berasal dari adanya kesalingtergantungan pekerjaan antara Dinas Lingkungan Hidup dan Kebersihan dengan Kelurahan, adanya ketergantungan pekerjaan satu arah, adanya dideferensiasi horisontal yang tinggi antar Kelurahan, serta perbedaan dalam kriteria evaluasi dan sistem pemberian imbalan dalam pelaksanaan Program Gerakan Mamuju Mapaccing.

\section{Pendahuluan}

Konflik merupakan fenomena yang tidak terpisahkan dari sebuah organisasi, sebab konflik bersumber dari perilaku manusia di dalamnya. Konflik didasari oleh ketidaksepadanan tujuan dan muncul dari perilaku-perilaku berlawanan. Robbins (1994: 451) mengatakan bahwa jika satu pihak menghalangi pencapaian tujuan pihak yang lain, maka konflik pun terjadi. Studi konflik awalnya berkembang dalam ilmu sosiologi, kemudian dilakukan oleh para ahli organisasi. Dalam studi organisasi, konflik merupakan salah satu aspek kajian perilaku organisasi yang kemudian dikenal dengan konflik organisasi. Studi konflik organisasi dapat dikaji pada tingkatan analisis individu, kelompok, maupun pada tingkatan analisis organisasi.

Konflik dalam analisis organisasi didefinisikan sebagai pertentangan yang terjadi ketika perilaku yang diarahkan pada pencapaian tujuan oleh suatu kelompok menghalangi atau mengancam tujuan-tujuan kelompok lainnya (Jones, 2007:394). Konflik organisasi umumnya terjadi karena adanya perbedaanperbedaan pendapat dan kepentingan diantara kelompok dalam suatu organisasi. Perbedaan tersebut disebabkan karena banyaknya sumber daya manusia dalam suatu organisasi yang berasal dari berbagai latar belakang yang berbeda dan tentu mempunyai tujuan yang berbeda pula dalam tujuan dan motivasi mereka dalam bekerja, sehingga potensial terjadinya konflik dalam organisasi cenderung tinggi.

Demikian halnya dengan organisasi pemerintah daerah tidak dapat menghindarkan diri dari konflik karena pemerintah daerah adalah organisasi berskala besar. Sebagai organisasi publik yang berskala besar, pemerintah Kabupaten Mamuju juga tidak terlepas dari konflik organisasi. Oleh sebab itu, pemerintah Kabupaten Mamuju juga harus mengelola konflik dengan baik. Salah satu konflik organisasi yang tengah dihadapi oleh pemerintah Kabupaten Mamuju ialah konflik dalam pelaksanaan Program Gerakan Mamuju Mapaccing. Program ini diharapkan mampu mengatasi permasalahan sampah di Kabupaten Mamuju. Sebagai upaya pencapaian tujuan progam, pemerintah Kabupaten Mamuju menyerahkan sebagian kewenangan pengelolaan sampah dari Dinas Lingkungan Hidup dan Kebersihan kepada Kecamatan dan Kelurahan. Pelimpahan 
kewenangan tersebut diatur dalam Peraturan Bupati Mamuju Nomor 39 Tahun 2018 Tentang Kebijakan dan Strategi Daerah (Jakstrada) Pengelolaan Sampah Rumah Tangga dan Sampah Sejenis Sampah Rumah Tangga (SSRT).

Dalam peraturan tersebut ditegaskan pada pasal 18 yang menjadi ruang lingkup pengambilan/pengangkutan sampah Kelurahan ialah ruas jalan sempit (lorong) dan pemukiman padat (Kompleks Perumahan). Sementara, ruang lingkup pengangkutan sampah oleh Dinas Lingkungan Hidup dan Kebersihan meliputi jalan-jalan besar dalam lingkup Kabupaten.

Namun aturan pelimpahan kewenangan tersebut, justru menimbulkan konflik organisasi antara Dinas Lingkungan Hidup dan Kebersihan dengan Kecamatan dan Kelurahan. Konflik yang terjadi ialah dengan saling melempar tanggung jawab antara satu sama lain. Sampah yang berhari-hari tidak diangkut di beberapa kawasan yang menjadi kewenangan Kelurahan membuat masyarakat melapor kepada pihak Dinas Lingkungan Hidup dan Kebersihan. Sementara Pihak Dinas Lingkungan Hidup dan Kebersihan (DLHK) beranggapan bahwa lokasi tersebut bukan lagi daerah pengangkutan sampahnya melainkan menjadi tanggung jawab Kelurahan setempat. Disisi lain, pihak Kelurahan tidak melaksanakan tugasnya dengan alasan merasa kewalahan dengan banyaknya volume sampah rumah tangga tidak sebanding dengan sarana dan prasarana yang masih kurang. Pada akhirnya, pihak Kelurahan masih sering meminta bantuan kepada Dinas Lingkungan Hidup dan Kebersihan dengan asumsi persoalan sampah dan kebersihan tetap menjadi tanggung jawab utama Dinas Lingkungan Hidup dan Kebersihan.

Uraian di atas menarik perhatian dalam kajian administrasi publik. Untuk itu, hal tersebut dijadikan sebagai objek dalam penelitian ini untuk menjawab pertanyaan penelitian apa saja sumber konflik dalam pelaksanaan Program Gerakan Mamuju Mapaccing di Kabupaten Mamuju?

\section{Kajian Literatur}

\section{Definisi Konflik}

Menurut Lacey (2003:17), konflik bisa didefinisikan "a fight, a collision, a struggle, a contest, opposition of interest, opinions of purpose, mental strife, agony" (suatu pertarungan, suatu benturan, suatu pergulatan, pertentangan kepentingankepentingan, opini-opini atau tujuan-tujuan pergulatan mental, penderitaan batin). Secara sederhana definisi mengenai konflik adalah dua jajaran kebutuhan atau lebih menarik dari arah-arah yang berlainan. Hal ini sejalan dengan definisi Cummings dalam Wahyudi dan Akdon (2011:17), konflik adalah suatu proses interaksi sosial dimana dua orang atau lebih, atau dua kelompok atau lebih, berbeda atau bertentangan dalam pendapat atau tujuan mereka.

Konflik merupakan suatu peristiwa atau kejadian yang tidak dapat dihindari dalam kehidupan organisasi. Oleh karena itu, seiring dengan dinamika dan perkembangan organisasi, maka organisasi yang dinamis membutuhkan konflik 
pada tingkat yang optimal guna meningkatkan pemahaman terhadap masalahmasalah yang muncul dalam setiap interaksi baik antar individu maupun antar kelompok.

\section{Konflik Organisasi dalam Perspektif Administrasi Publik}

Studi konflik organisasi khususnya pada organisasi publik merupakan bidang kajian yang relevan dalam administrasi publik karena konflik organisasi merupakan tema kajian teori organisasi, sedangkan teori organisasi merupakan fokus administrasi publik. Teori organisasi adalah studi tentang bagaimana organisasi-organisasi berfungsi dan bagaimana organisasi-organisasi mempengaruhi dan dipengaruhi oleh lingkungan dimana organisasi-organisasi tersebut beroperasi. Teori organisasi mempelajari desain, operasi, perubahan dan redesain organisasi guna memelihara dan meningkatkan efektifitasnya (Jones, 2007:7).

Topik kajian utama teori organisasi adalah struktur organisasi, desain dan perubahan organisasi, serta budaya organisasi (Jones, 2007: 8). Termasuk dalam topik perubahan organisasi adalah tipe perubahan organisasi, transformasi organisasi, pembuatan keputusan, pembelajaran, manajemen pengetahuan dan teknologi informasi, konflik kekuasaan, dan politik (Jones, 2007: 269). Berdasarkan uraian tersebut konflik organisasi, khususnya organisasi publik, merupakan bidang kajian yang relevan dari administrasi publik sehingga studi ini dapat bermanfaat bagi pengembangan disiplin administrasi publik khususnya teori organisasi.

Robbins (1994:453) mengatakan bahwa konflik dalam organisasi disebut sebagai The Conflict Paradoks, yaitu pandangan bahwa disatu sisi konflik hanya merintangi koordinasi dan kerja sama tim hingga menimbulkan kerusakan dalam kelompok, tetapi disisi lain konflik dipandang tidak hanya menjadi kekuatan positif dalam suatu kelompok, tetapi juga konfli dibutuhkan demi meningkatkan keefektifan organisasi dengan merangsang perubahan dan memperbaiki proses pengambilan keputusan. Pandangan tersebut kemudian disebut oleh Robbins sebagai The Traditional View of Conflict dan The Interactionist View of Conflict.

Robbins (1994:457) mengidentifikasi sejumlah faktor berbeda dapat menimbulkan konflik organisasi. Beberapa faktor bersifat psikologis, artinya konflik tersebut berkaitan dengan karakteristik perseorangan para karyawan. Hal inilah yang menjelaskan bahwa ada orang yang mempunyai kesulitan tersebut tidak ada kaitannya dengan kemampuan kerja atau interaksinya yang formal. Namun yang menjadi perhatian adalah konflik yang disebabkan oleh masalah struktural. Peninjauan kembali berikut ini mencerminkan beberapa sumber konflik organisasi yang berfokus pada struktur organisasi, yakni:

\section{Kesalingtergantungan Pekerjaan}

Kesalingketergantungan pekerjaan merujuk kepada sejauh mana dua unit dalam sebuah organisasi saling tergantung satu sama lain pada bantuan, informasi, kerelaan atau aktivitas koordinasi lain untuk menyelesaikan tugas masing-masing secara efektif (Robbins 1994:458). 
2. Ketergantungan Pekerjaan Satu Arah

Prospek terjadinya konflik akan lebih besar jika sebuah unit secara unilateral bergantung pada yang lain. Berlawanan dengan kesalingketergantungan, ketergantungan pekerjaan satu arah berarti bahwa keseimbangan telah bergeser. Prospek dari konflik pasti lebih tinggi karena unit yang dominan mempunyai dorongan yang sedikit saja untuk bekerja sama dengan unit yang berada di bawahnya.

3. Dideferensiasi Horisantal yang Tinggi

Makin besar perbedaan yang terdapat diantara unit, makin besar pula kemungkinan timbulnya konflik. Jika unit-unit dalam organisasi amat diderensiasi, maka tugas yang dilakukan masing-masing unit dan sub lingkungannya yang ditangani oleh masing-masing sub unit cenderung tidak sama. Hal ini, pada gilirannya, akan mengakibatkan terjadinya perbedaan internal yang cukup besar diantara unit-unit.

\section{Formalisasi yang Rendah}

Peraturan mengurangi konflik dengan mengurangi kedwi-artian. Formalisasi yang tinggi membangun cara-cara yang distandarisasi bagi unitunit saling bergaul. Penetapan mengenai peran harus jelas sehingga para anggota unit tersebut mengetahui apa yang diharapakan dari yang lain. Sebaliknya, jika formalisasi rendah, potensi terjadinya pertikaian mengenai batas-batas kekuasaan akan meningkat.

\section{Ketergantungan pada Sumber-Sumber Bersama yang Langka}

Potensi konflik tinggi jika dua unit atau lebih bergantung pada sumber daya yang langka, seperti ruang gerak fisik, peralatan, dana operasi, alokasi anggaran modal atau jasa-jasa staf yang disenteralisasi seperti pool untuk mengetik. Potensi tersebut meningkat lebih lanjut jika anggota-anggota unit merasakan bahwa kebutuhan individualnya tidak dapat diperolehnya dari pool sumber daya yang tersedia ketika kebutuhan unit lain dipenuhi.

6. Perbedaan Dalam Kriteria Evaluasi dan Sistem Imbalan

Makin banyak evaluasi dan imbalan manajemen yang menekankan prestasi setiap departemen secara terpisah-pisah ketimbang secara gabungan, maka makin besar pula konfliknya.

\section{Pengambilan Keputusan Partisipatif}

Pengambilan keputusan secara bersama, dimana mereka yang akan terkena oleh suatu keputusan diikutsertakan dalam badan yang mengambil keputusan, akan mendorong terjadinya konflik. Proses partisipatif memberi kesempatan yang lebih besar untuk mengutarakan perselisihan yang ada dan menimbulkan ketidaksepakatan.

\section{Keanekaragaman Anggota}


Makin heterogen anggota, makin kecil kemungkinan mereka bekerja dengan tenang dan bersama-sama. Telah ditemukan bahwa ketaksamaan para individu, seperti latar belakang, nilai-nilai, pendidikan, umur, dan pola-pola sosial akan lebih mengurangi kemungkinan hubungan antar pribadi antara wakil-wakil unit pada gilirannya akan mengurangi jumlah kerja sama antara masing-masing unit.

\section{Ketidaksesuaian Status}

Konflik terstimulasi jika terjadi ketidaksesuain dalam penilaian status atau karena adanya perubahan dalam hierarki status. Misalnya, peningkatan konflik ditemukan jika tingkat dimana status pribasi, atau bagaimana orang melihat pribadinya sendiri, dan tingkat dari perwakilan dari departemen berebda dalam urutan tingkatan dimensi status. Dimensi tersebut termasuk panjangnya masa kerja, umur, pendidikan dan upah.

\section{Ketidakpuasan Peran}

Robbins menekankan bahwa cara orang mempersepsikan dirinya sendiri dalam posisi masing-masing dapat cukup mempengaruhi prestasi mereka dan dengan demikian potensi bagi timbulnya konflik antara mereka dengan teman sejawataya dalam unit mereka dan unit-unit yang berdampingan. Jika orang menerima sebuah peran, maka ia membawa serta sejumlah harapan dan aspirasi. Jika harapan-harapan tersebut tidak dipenuhi (jika pekerjaan tidak menantang atau imbalan tidak mencukupi), maka individu tersebut dapat memperlihatkan frustasi mereka dalam sejumlah tindakan.

\section{Distorsi Komunikasi}

Salah satu sumber konflik yang sering dikemukakan adalah kesukaran dalam komunikasi. Kasus yang jelas adalah komunikasi vertikal. Jika komunikasi diteruskan dari atas ke bawah dalam sebuah hirarki, komunikasi cenderung mengalami kedwi-artian dan distorsi. Distorsi koumnikasi juga dapat pulat terjadi secara horisontal. Semakin sedikit pengetahuan yang dimiliki antar unit, maka akan semakin sedikit pula kerja sama yang terjadi, sehingga menyebabkan permintaan yang tidak masuk akal antar unit.

\section{Metode Penelitian}

Dalam peneitian ini peneliti menggunakan pendekatan penelitian kualitatif dengan alasan agar peneliti dapat mengalisis dan menjelaskan fenomena tentang apa yang dialami oleh Organisasi Pemerintah Daerah Kabupeten Mamuju khususnya pada konflik organisasi antara Dinas Lingkungan Hidup dan Kebersihan dengan Kecamatan dan Kelurahan dalam hal pelaksanaan Program Gerakan Mamuju Mapaccing. Penelitian ini akan dilaksanakan di Kabupaten Mamuju dengan pengambilan studi kasus di Kecamatan Mamuju. Alasan pemilihan lokasi di Kecamatan Mamuju karena diantara kecamatan lainnya, program Mamuju Mapaccing lebih aktif diterapkan di Kecamatan ini. Untuk itu, 
ada 4 kelurahan yang akan menjadi lokus dalam penelitian ini yaitu Kelurahan Binanga, Rimuku, Karema dan Mamunyu.

Untuk memperjelas batasan-batasan dalam penelitian ini, peneliti memfokuskan penelitian ini pada manajemen konflik antara Dinas Lingkungan Hidup dan Kebersihan dengan Kecamatan dan/atau Kelurahan. Untuk itu, peneliti menggunakan teori konflik organisasi oleh Robbins (1994), yaitu sumber dan resolusi konflik oleh Robbins.

Untuk memperoleh data guna kepentingan penelitian serta adanya hasil yang representatif, maka diperlukan informan yang memahami dan mempunyai kaitan dengan permasalahan yang sedang diteliti. Informan yang dimaksud adalah:

1. Kepala Dinas Lingkungan Hidup dan Kebersihan

2. Staff Pengawas Pegawai Dinas Lingkungan Hidup dan Kebersihan

3. Kepala Camat

4. Kepala Lurah/Desa

5. Petugas Kebersihan Kelurahan

6. Petugas Kebersihan Dinas Lingkungan Hidup dan Kebersihan

Dalam penelitian ini jenis data yang dikumpulkan adalah data primer dan data sekunder. Untuk mengumpulkan data tersebut peneliti menggunakan beberapa instrumen pengumpulan data yaitu wawancara, observasi, dan kajian kepustakaan. Analisis data yang dilakukan dalam penelitian ini terdiri dari tiga sub proses yang saling terkait (Miles \& Huberman,1984,1994); reduksi data, penyajian data, dan pengambilan kesimpulan / verifikasi.

\section{Hasil Penelitian dan Pembahasan}

Berdasarkan hasil penelitian, diperoleh sumber konflik antara pihak Dinas Lingkungan Hidup dan Kebersihan, pihak Kecamatan, dan pihak Kelurahan dalam pelaksanaan program Gerakan Mamuju Mapaccing.

\section{Kesalingtergantungan Pekerjaan}

Kesalingtergantungan pekerjaan, yaitu merujuk pada sejauh mana kesalingtergantungan pekerjaan dalam hal ini pelaksanaan program Gerakan Mamuju Mapaccing antara Kelurahan, Kecamatan dan Dinas Lingkungan Hidup dan Kebersihan (DLHK). Apabila kesalingtergantungan besar, maka prospek terjadinya konflik juga cenderung besar. Kesalingtergantungan pekerjaan dalam pelaksanaan program Gerakan Mamuju Mapaccing dapat dilihat dari kordinasi, kerjasama dan pembagian kerja antar pihak.

Temuan penelitian menunjukkan bahwa antara Dinas Lingkungan Hidup dan Kebersihan dengan Kelurahan terjadi kesalingtergantungan pekerjaan yang sangat erat dalam proses pengangkutan sampah. Petugas kebersihan kelurahan sangat bergantung pada mobil container dan truk amrol dari Dinas Lingkungan Hidup dan Kebersihan. Jika armada Dinas Lingkungan Hidup dan Kebersihan datang terlambat maka petugas kebersihan pihak Kelurahan juga tidak dapat 
memindahkan Sampah Rumah Tangga (SRT) yang telah diangkutnya ke Tempat Pembuangan Sampah (TPS) Sementara. Begitu pula sebaliknya, pihak Dinas Lingkungan Hidup dan Kebersihan tidak dapat mengangkut sampah ke TPA (Tempat Pembuangan Akhir) apabila pihak kelurahan masih mengangkut Sampah Rumah Tangga dari kelurahan.

Hal ini berdasarkan hasil wawancara dengan kepala Dinas Lingkungan Hidup dan Kebersihan bahwa:

"Kordinasinya baik, karena pasar baru yang menjadi lokasi TPSS (tempat pengumpulan sampah sementara), semua lurah menuju kesana. Kami jemput, kemudian DLHK angkut ke TPA. Mobil container kami selalu stand by setiap hari pukul 08.00-10.00. Jadi, jika motor fukuda dari kelurahan terlambat mengangkut sampahnya ke TPSS, maka sampah tersebut akan tinggal dan akan diangkut untuk keesokan harinya."

Dengan demikian, dapat disimpulkan bahwa kemungkinan terjadinya konflik antara Dinas Lingkungan Hidup dan Kebersihan dengan Kelurahan sangat besar. Hal ini dikarenakan adanya kesalingtergantungan yang sangat kuat dalam pelaksanaan program Gerakan Mamuju Mapaccing terutama dalam hal pengangkutan sampah. Salah satu pihak tidak dapat melaksanakan tugasnya apabila pihak lain tidak bekerja.

\section{Ketergantungan Pekerjaan Satu Arah}

Ketergantungan pekerjaan satu arah, yaitu sejauh mana pihak Kecamatan dan Dinas Lingkungan Hidup dan Kebersihan (DLHK) bekerja sama dengan pihak Kelurahan sebagai unit yang secara langsung bersentuhan dengan masyarakat. Apabila pihak yang dominan dalam hal ini Kecamatan dan DLHK mempunyai dorongan yang sedikit kepada pihak Kelurahan, maka terjadinya konflik lebih besar. Untuk melihat sejauh mana ketergantungan pekerjaan satu arah oleh pihak Dinas dan pihak Kelurahan, maka digunakan parameter keseimbangan dan proses penyelesaian masalah oleh masing-masing pihak.

Berdasarkan hasil penelitian, diketahui bahwa pihak Dinas Lingkungan Hidup dan Kebersihan tidak lagi ingin turut andil dalam pengangkutan sampah yang telah menjadi wilayah kelurahan. Hal ini berdasarkan pernyataan dari Kepala Dinas Lingkungan Hidup bahwa :

"sekarang sudah ada pelimpahan sebagian kewenangan ke kelurahan, tetapi masih sering saya angkut sampah di wilayah kelurahan. Seharusnya kan tidak seperti itu."

Di sisi lain, pihak kelurahan masih sering kewelahan dalam mengatasi sampah di wilayah mereka masing-masing, sehingga masih membutuhkan bantuan dari pihak Dinas. Hal ini berdasarkan hasil wawancara dengan Lurah Karema yang menyatakan bahwa:

"iya saya akui itu, sering memang DLHK mengangkut sampah di wilayah saya, dan itu bukan SLB. Karena memang kami tidak mampu lagi mengankut sampah itu, sehingga dihubungi DLHK. Nanti DLHK yang angkut." 
Hal tersebut juga didukung oleh Camat mamuju yang memberikan pernyataan bahwa :

"Memang ada pelimpahan kewenangan, tapi kan armada yang dibagikan ke kelurahan tidak cukup, jadi wajar saja jika kelurahan tidak mampu mengatasi kemudian meminta bantuan kepada dinas."

Pihak Dinas Lingkungan Hidup dan Kebersihan sebagai unit yang dominan dalam pelaksanaan program Gerakan Mamuju Mapaccing mempunyai dorongan yang sedikit terhadap unit yang secara langsung bersentuhan dengan masyarakat yakni pihak Kelurahan. Hal ini dilihat dari dorongan penyelesaian masalah sampah oleh pihak DLHK di wilayah Kelurahan tergolong sedikit. Artinya, pihak DLHK memang menindak secara nyata dengan mengangkut sampah di wilayah kelurahan, namun secara instansi, pihak DLHK mengeluhkan hal tersebut. Hal ini berdasarkan pernyatan Kepala Dinas Lingkungan Hidup dan Kebersihan :

“tidak apa-apa kalau hanya sekali-kali saya bantu mereka, tapi kalau berkali-kali, kami juga tekor karena anggaran kan tidak ada. Kalau saya bantu kelurahan kan bensin lagi, biaya operasional dan tambahan honor untuk petugas kebersihan. Lama-lama kami juga tekor kan yang dianggarkan hanya sesuai wilayah masing-masing."

Dengan berbagai hasil wawancara di atas, maka dapat disimpulkan bahwa antara Dinas Lingkungan Hidup dan Kebersihan dengan Kelurahan cenderung rawan terjadinya konflik dari segi ketergantungan pekerjaan satu arah.

\section{Dideferensiasi Horisantal yang Tinggi}

Dideferensiasi horisantal yang tinggi, yaitu merujuk pada sejauh mana perbedaan antar unit baik dari segi sumber daya manusia maupun dari sarana dan pra sarana dalam pelaksanaan Program Gerakan Mamuju Mapaccing. Unit yang dimaksud ialah Dinas Lingkungan Hidup dan Kebersihan, Kecamatan dan Kelurahan. Apabila dalam pembagian unit terdapat diferensiasi horisontal yang tinggi, maka jelas konflik tidak dapat terhindarkan.

Hasil wawancara dengan Kepala Lurah Binanga mengatakan bahwa:

"diantara kelurahan yang lain, Kelurahan Binanga jauh lebih padat dibandingkan kelurahan lainnya seperti Kelurahan Rimuku dan Kelurahan Karema. Namun, mereka mendapat masing-masing 5 unit motor fukuda sementara disini hanya 4 unit. Motor fukuda ini dibagi oleh pihak DLHK melalui Kecamatan, jadi Kecamatan hanya menyalurkan saja, pembagian per kelurahan itu DLHK semua yang atur."

Temuan penelitian menunjukkan bahwa pembagian sarana dan prasarana dalam pelaksanaan program Gerakan Mamuju Mapaccing tidak adil dan tidak sesuai sebagaimana mestinya. Wilayah yang lebih sempit dengan jumlah penduduk yang sedikit mendapat sarana dan prasarana yang banyak, seperti Kelurahan Simboro Kecamatan Simboro mendapat 11 unit motor fukuda. Sementara, wilayah yang cukup luas diantara Kecamatan dan Kelurahannya lainnya se-Kabupaten Mamuju dengan jumlah penduduk yang sangat padat mendapat sarana dan prasarana berupa motor fukuda yang sedikit, seperti Kelurahan Binanga 4 unit, kelurahan Karema dan Kelurahan Rimuku masing- 
masing 5 unit, dan 3 unit Kelurahan Mamunyu untuk Kecamatan Mamuju. Selain itu, dideferensiasi horisontal yang tinggi juga dapat dilihat dari pembagian pakaian seragam lengkap antara petugas kebersihan, yaitu petugas kebersihan kelurahan tidak mendapat pakaian seragam lengkap seperti petugas kebersihan DLHK.

Oleh karena itu, dapat disimpulkan bahwa besar kemungkinan terjadinya konflik yang disebabkan oleh dideferensiasi horisontal yang tinggi antar Kelurahan dan Kecamatan, serta antar petugas kebersihan.

\section{Formalisasi yang Rendah}

Formalisasi yang rendah, yaitu mengenai aturan-aturan, Standar Operasioanl Prosedur (SOP) serta batas kewenangan antara Pihak Dinas Lingkungan Hidup dan Kebersihan (DLHK), Kecamatan dan Kelurahan. Apabila tidak jelas aturan dan batasnya, maka potensi terjadinya konflik besar. Selain itu, ditinjau pula sejauh mana pihak-pihak tersebut memahami tugas pokok masingmasing. Artinya, meskipun ada aturan jika para pihak kurang memahami aturan masing-masing maka besar terjadinya konflik.

Hasil penelitian menunjukkan bahwa aturan-aturan serta SOP dalam pelaksanaan program Gerakan Mamuju Mapaccing sangat jelas. Pemahaman para pihak pun terkait aturan batas wilayah serta jenis sampah yang harus diangkut juga jelas, sehingga para pihak baik DLHK, Kecamatan dan Kelurahan serta masingmasing para petugas kebersihan melaksanakan tugasnya sesuai dengan turan dan batas-batas kewenangan yang telah dibuat dalam peraturan.

Hal ini berdasarkan pernyataan dari Kepala Lurah Simboro yang mengatakan bahwa:

"sangat jelas pembagian wilayahnya. DLHK di jalan poros,sementara kelurahan di lorongnya masing-masing. Petugas kebersihan juga sudah tau yang mana wilayah mereka yang harus diangkut dan yang mana tidak diangkut"

Dengan demikian, dapat ditarik sebuah kesimpulan bahwa tidak terjadi konflik yang disebabkan oleh formalisasi yang rendah antara pihak Kelurahan dan DLHK karena masing-masing tugas dan wewenang dijalankan sesuai dengan peraturan.

\section{Ketergantungan pada Sumber-sumber Bersama yang Langka}

Ketergantungan pada sumber-sumber bersama yang langka, yaitu mengenai kelangkaan sumber daya yang dibutuhkan dalam pelaksanaan program Gerakan Mamuju Mapaccing. Apabila terdapat sumber daya yang langka dan paling dibutuhkan setiap unit, maka prospek terjadinya konflik semakin besar. Hal ini disebabkan karena setiap unit akan berebut untuk mendapatkan sumber daya tersebut.

Temuan penelitian menunjukkan bahwa tidak ada sumber-sumber bersama yang langka dalam pelaksanaan program Gerakan Mamuju Mapaccing di Kabupaten Mamuju, sehingga tidak akan terjadi konflik yang disebabkan oleh sumber konflik ini. 


\section{Perbedaan dalam Kriteria Evaluasi dan Sistem Imbalan}

Perbedaan dalam kriteria evaluasi dan sistem imbalan, yaitu bagaimana evaluasi dan pemberian imbalan (reward) bagi pihak yang telah melaksanakan tugasnya dalam program Gerakan Mamuju Mapaccing dengan baik. Apabila terdapat perbedaan antar unit maka besar kemungkinan terjadinya konflik.

Dari hasil penelitian, diketahui bahwa proses evaluasi yang dilakukan masing-masing pihak berbeda serta dengan kriteria yang berbeda pula. Kepala Dinas Lingkungan Hidup dan Kebersihan mengevaluasi kerja anggotanya dengan cara keliling wilayah setiap hari. Hal ini berdasarkan wawancara dengan beliau yang mengatakan bahwa :

"sejauh ini evaluasi yang saya lakukan kepada anggotaku ialah melihat wilayah kerja mereka masing-masing. Setiap hari saya keliling ke wilayahnya, jika ada sampah yang tidak terangkut, segera saya telepon anggota untuk segera diangkut."

Sementara Camat Mamuju mengevaluasi para keluharan dengan mengadakan pertemuan rutin setiap sekali sebulan untuk membahas pelaksanaan program Gerakan Mamuju Mapaccing. Hal ini berdasarkan pernyataan beliau yang mengatakan bahwa:

"Evaluasi setiap 1 bulan rutin, dengan cara dihadirkan semua petugas kebersihan kemudian ditanya apa kendalanya, dan itu kendalanya saja fukuda. Mereka juga berharap gaji mereka dinaikkan karena memang gajinya sekarang ini hanya 1 jt itu sudah termasuk uang makan."

Kelurahan berpendapat bahwa evaluasi dilakukan melalui keluhan-keluhan dari masyarakat. Kepala Kelurahan Simboro mengatakan bahwa:

"evaluasi yang dilakukan itu tentunya mereka bisa lihat dari keluhan masyarakat. Sejauh ini kelurahan Simboro, juga masih ada keluhan."

Di sisi lain, petugas kebersihan kelurahan mengemukakan bahwa tidak ada evaluasi dan tidak ada sistem pemberian imbalan, melainkan pembayaran insentif setiap bulan sering mengalami keterlambatan.

Dari berbagai pernyataan di atas, maka dapat disimpulkan bahwa tidak adanya kejelasan kriteria evaluasi dalam pelaksanaan program Gerakan Mamuju Mapaccing sehingga dapat memicu terjadinya konflik.

\section{Pengambilan Keputusan Partisipatif}

Pengambilan keputusan partisipatif, yaitu apabila dalam pelaksanaan program Gerakan Mamuju Mapaccing terlalu banyak proses partisipatif, maka akan menimbulkan perselisihan dan ketidaksepakatan. Temuan penelitian menunjukkan bahwa tidak terjadi konflik yang disebabkan oleh pengambilan keputusan partisipatif, karena tidak ada forum yang disediakan untuk menampung apresiasi pihak-pihak yang terlibat dalam pelaksanaan program Gerakan Mamuju Mapaccing.

\section{Keanekaragaman Anggota}


Keanekaragaman anggota, yaitu semakin beragamnya anggota dari segi latar belakang suku, nilai-nilai dan umur maka semakin besar pula peluang terjadinya konflik. Dari berbagai informan, diperoleh informasi bahwa dalam pelaksanaan program Gerakan Mamuju Mapaccing ada banyak perbedaan latar belakang individu. Selain itu, dari hasil observasi secara langsung yang dilakukan oleh penulis juga melihat ada perbedaan umur di kalangan petugas kebersihan, ada yang masih berumur 19 tahun hingga umur lanjut usia (Lansia). Namun, meski terdapat perbedaan dari latar belakang, suku maupun usia, para operator fukuda tetap bekerja sama dengan baik. Staff pengawas kebersihan mengemukakan bahwa:

"kami disini berasal dari berbagai suku, ada suku bugis, makassar dan mandar. Karena asal kami juga berbeda-beda, ada dari Polman, Pinrang, Sidrap, Makassar dan ada juga penduduk asli yakni Mamuju."

Dengan demikian, dapat disimpulkan bahwa peluang terjadinya konflik yang disebabkan oleh keanekaragaman anggota besar. Akan tetapi, dari keterangan para informan tersebut menunjukkan bahwa keanekaragaman ini tidak menjadi kendala mereka dalam pelaksanaan program Gerakan Mamuju Mapaccing.

\section{Ketidaksesuaian Status}

Ketidaksesuaian status, yaitu masa kerja, senioritas, serta pendidikan dalam hirarki status. Apabila ada pihak yang menduduki sebuah jabatan dan tidak sesuai dengan statusnya, maka kemungkinan terjadinya konflik sangat besar.

Dalam pelaksanaan program Gerakan Mamuju Mapaccing, masa kerja, senioritas serta pendidikan dalam hirarki status sangat dipertimbangkan. Hasil penelitian menunjukkan bahwa status petugas kebersihan sangat ditentukan oleh masa kerjanya. Staff Pengawas Petuga Kebersihan DLHK mengatkan bahwa:

"saya dulunya hanya sopir amrol saja dan hanya lulusan SMA, nah pas ada program bupati yang mengangkat PNS K2 yang mulai bekerja sejak tahun 2005 ke bawah, saya masukkan berkasku dan diangkat jagi PNS. Jadi para petugas kebersihan ini semua, yang ada ijazah terakhirnya kalau ada lagi nanti pengangkatan PNS, bisa saja mereka juga terangkat sesuai dengan masa kerjanya."

Dari pernyataan tersebut diketahui bahwa dalam pelaksanaan program Gerakan Mamuju Mapaccing status sangat ditentukan oleh masa kerja dan pendidikan. Oleh karena itu, tidak terjadi konflik yang disebabkan oleh ketidaksesuaian status.

\section{Ketidakpuasan Peran}

Ketidakpuasan peran, yaitu apabila pegawai tidak puas terhadap peran yang saat ini diembannya. Ketika seorang pegawai tidak puas dengan perannya, maka besar peluang terjadinya konflik. Kepuasan peran dapat dilihat dari ketidaksesuaian status dengan peran, serta adanya harapan yang tidak terpenuhi. Dari hasil penelitian, masing-masing personal puas kana peran yang saat ini diembaninya, sehingga dapat disimpulkan bahwa tidak terjadi konflik yang 
disebabkan oleh adanya ketidakpuasan peran dalam pelaksanaan program Gerakan Mamuju Mapaccing.

\section{Distorsi Komunikasi}

Distorsi komunikasi, yakni sejauh mana komunikasi dan koordinasi yang dibangun antar pihak Dinas lingkungan Hidup dan Kebersihan, pihak Kecamatan dan Kelurahan dalam pelaksanaan program Gerakan Mamuju Mapaccing. Jika arah komunikasi cenderung tidak jelas dan tepat, maka jelas akan mengundang terjadinya konflik. Kepala Camat Mamuju memberikan keterangan :

"kami tetap koordinasi dengan DLHK ketika ada permasalahan. Begitu juga dengan para Lurah. Kalau ada keluhan masyarakat, langsung saya hubungi lurahnya untuk segera mengangkut sampahnya."

Sementara Lurah Binanga mengatakan bahwa :

"Koordinasi dengan kecamatan tetap kita jalin karena bagaimana pun juga OPD dari kelurahan ialah kecamatan. Sementara komunikasi dengan DLHK melalui walki talkie."

Temuan penelitian tersebut menujukkan bahwa komunikasi antara pihak Dinas lingkungan Hidup dan Kebersihan, pihak Kecamatan dan Kelurahan dalam pelaksanaan program Gerakan Mamuju Mapaccing terjalin baik dan jelas. Dengan demikian, tidak terjadi konflik yang disebabkan oleh distorsi komunikasi antar pihak.

\section{Kesimpulan}

Berdasarkan hasil penelitian yang telah dilakukan oleh peneliti, dengan menggunakan indikator Teori Konflik yang dikemukakan oleh Robbins (1998), maka dapat ditarik kesimpulan : Sumber konflik dalam pelaksanaan Program Gerakan Mamuju Mapaccing di Kabupaten Mamuju berdasarkan Teori Konflik yang dikemukakan oleh Robbins (1998) ialah :

1. adanya kesalingtergantungan pekerjaan,

2. adanya ketergantungan pekerjaan satu arah,

3. adanya dideferensiasi horisontal yang tinggi, serta

4. perbedaan dalam kriteria evaluasi dan sistem imbalan.

\section{Persantunan}

Dalam penelitian ini, banyak kendala dan hambatan yang dihadapi oleh Penulis. Namun, berkat bimbingan dan arahan dari pembimbing, segala hambatan tersebut dapat terselesaikan. Untuk itu, dengan segala kerendahan hati Penulis mengucapkan rasa terima kasih yang tak terhingga kepada Prof. Dr. Alwi, M.Si 
serta Dr. Gita Susanti, M.Si yang telah meluangkan banyak waktu untuk memberikan arahan, bimbingan dan motivasi yang sangat berarti sejak proses studi, penelitian hingga terselesainya penulisan penelitian ini.

\section{Daftar Pustaka}

http://mamujukab.go.id

Huberman, A. M., \& Miles, M. B. (1994). Data Management and Analysis Methods. In N. K. Denzin \& Y. S. Lincoln (Eds.), Handbook of qualitative research (pp. 428 444). Thousand Oaks, CA, US: Sage Publications, Inc.

Lacey, H. (2003). How to Resolve Conflict in the Workplace: Mengelola Konflik di Tempat Kerja. Jakarta: Gramedia Pustaka Utama.

Peraturan Bupati Mamuju Nomor 39 Tahun 2018 tentang Kebijakan dan Strategi Daerah (Jakstrada) Pengelolaan Sampah Rumah Tangga Dan Sampah Sejenis Rumah Tangga (SSRT).

Peraturan Daerah Kabupaten Mamuju Nomor 6 Tahun 2016 Tentang Pembentukan Dan Susunan Perangkat Daerah Kabupaten Mamuju

Peraturan Daerah Nomor 02 Tahun 2017 tentang Pengelolaan Sampah di Kabupaten Mamuju

Robbins, Stephen P and Timothy A Judge. (2013). Organizational Behavior $15^{\text {th }}$ ed. Pearson.

Robbins, Stephen P and Timothy A Judge. (2015). Perilaku Birokrasi: Organizational Behavior Edisi 16, Jakarta Selatan: Salemba Empat.

Robbins, Stephen P. (1994). Teori Organisasi: Struktur, Desain dan Aplikasi, Jakarta: Arcan.

Undang-Undang Nomor 18 Tahun 2008 tentang Pengelolaan Sampah

Wahyudi, Akdon. (2011). Manajemen Konflik dalam Organisasi : Pedoman Praktis Bagi Pemimpin Visioner. Bandung : Alfabeta CV 